\title{
Autochthonous Probiotics in Meat Products: Selection, Identification, and Their Use as Starter Culture
}

\author{
Paulo E. S. Munekata ${ }^{1}$, Mirian Pateiro ${ }^{1} \mathbb{D}$, Wangang Zhang ${ }^{2}$, Rubén Domínguez ${ }^{1} \mathbb{}$, \\ Lujuan Xing ${ }^{2}$, Elena Movilla Fierro ${ }^{3}$ and José M. Lorenzo $1,4, * \mathbb{B}$ \\ 1 Centro Tecnológico de la Carne de Galicia, rúa Galicia n 4, Parque Tecnológico de Galicia, San Cibrao das \\ Viñas, 32900 Ourense, Spain; paulosichetti@ceteca.net (P.E.S.M.); mirianpateiro@ceteca.net (M.P.); \\ rubendominguez@ceteca.net (R.D.) \\ 2 Key Laboratory of Meat Processing and Quality Control, Ministry of Education China, Jiangsu Collaborative \\ Innovation Center of Meat Production and Processing, Quality and Safety Control, College of Food Science \\ and Technology, Nanjing Agricultural University, Nanjing 210095, China; \\ wangang.zhang@njau.edu.cn (W.Z.); lujuanxing@njau.edu.cn (L.X.) \\ 3 Complejo Hospitalario Universitario de Ourense, 32005 Ourense, Spain; elemofierro@hotmail.com \\ 4 Área de Tecnología de los Alimentos, Facultad de Ciencias de Ourense, Universidad de Vigo, \\ 32004 Ourense, Spain \\ * Correspondence: jmlorenzo@ceteca.net
}

Received: 15 October 2020; Accepted: 19 November 2020; Published: 21 November 2020

\begin{abstract}
The increasing demand for functional food is pushing the food industry to innovate the conventional and well-known foods. Producing functional foods, especially with probiotics in meat products, is an intricate and multistage task that involves: the selection of microorganisms with probiotic potential, the identification at strain level, and the evaluation of probiotic strains in the processing of meat products. The resistance to digestion, followed by the successful colonization in the small intestine and the safety are the main criteria used to select and identify (at strain level) a probiotic, as reported in recent studies about the autochthonous microbiota of meat products. Further insertion (as starter culture) in a meat system for fermentation is the simplest approach to obtain a probiotic meat product. Among the innumerous microorganisms naturally found in meat products, lactic acid bacteria (LAB) play a central role by fitting in both probiotic and meat products processing criteria.
\end{abstract}

Keywords: functional meat products; LAB; autochthonous bacteria; inoculum; quality

\section{Introduction}

The fermentation of meat dates back to centuries ago when meat cuts were spontaneously fermented by its natural (autochthonous) microbiota without any control of processing conditions to preserve meat [1]. In European countries, this practice is believed to have originated in the Mediterranean countries and posteriorly spread to other countries where particular aspects of each location influenced the characteristics of each product, which include the environmental microbiota, ingredients, and practices in the processing [2]. Although the characteristics of traditionally produced (texture, color, and flavor, for instance) are highly appreciated, producing fermented meat products using autochthonous microorganisms (naturally present in meat or from environment where the processing is carried out) is an important issue in terms of public health [3,4]. However, consumers perceive traditionally produced meat products with higher quality even though the risk associated 
with their consumption (growth of pathogenic bacteria and accumulation of toxins and harmful compounds) [4].

Improving the characteristics of meat products is another important aspect that modern consumers consider relevant in the moment of purchase, especially when a health benefit is the additional attribute [5]. Moreover, the combination of traditional practices with modern strategies to produce meat products should not be seen as contrasting concepts [6]. However, the increasing interest in functional food products has brought important challenges for the food industry, especially in muscle product category $[7,8]$. The use of probiotics is part of the successful strategies to improve foods from their conventional or traditional production form to functional food category, especially for fermented food products [9]. The ingestion of living microorganisms (also known as probiotics) in adequate amount (6-7 $\log$ CFU/g) has been associated with several health benefits for the host. Functional foods can be defined as food products with additional benefits beyond those related to basic nutrients [10,11].

In modern times, the control of the processing conditions and quality of fermented meat products has greatly improved, especially because of the use of specific microorganisms such as the lactic acid bacteria (LAB) [12,13]. LAB plays a central role as one of the most studied groups of microorganisms for the development of functional foods because of their benefits to human health, potential to prevent the formation of toxic compounds (such as biogenic amines), and also being Generally Recognized as Safe (GRAS) [14-16]. Moreover, LAB has been associated with health benefits such as improving immunity, anti-oxidative capacity, and peristalsis in healthy subjects [17], improving the glycemic control and indicators of cardiovascular diseases in diabetic nephropathy patients [18], and reducing intestinal inflammation in ulcerative colitis patients [19].

The use of starter cultures can bring several benefits in comparison to spontaneous fermentation: better control of the fermentation as a whole, reduce the ripening time, reduce the possibility of pathogenic microorganism growth, and also improve the preservation of quality between batches $[20,21]$. However, selecting an adequate starter culture for the development of a functional meat product is a challenging task because of the complexity of each step and the numerous assays required. The Figure 1 indicates a schematic representation of the screening approach for the selection of probiotic starter cultures from autochthonous microbiota of meat products.

The first step consists in the evaluation of the probiotic potential. In this stage, the influence of stressors of the digestion, intestinal colonization, and safety aspects is decisive to define the probiotic viability of an isolate [11]. Once the dietary probiotics are ingested, the microorganisms are exposed to a hostile environment including the body temperature, gastric juice, hydrochloric acid, and bile salts. Prevailing to these stressors is an important indicator that viable cells can reach the intestine. In the following criteria stage, the viable cells are expected to colonize the intestine. This task is achieved by adhering to epithelial cells, auto-aggregation (small agglomerations of microbial cells), having high cell surface hydrophobicity, inhibiting the growth of pathogenic microorganisms that compete for the limited resources in the intestine, and also by co-aggregating to pathogenic cell and facilitating its release in the feces, for instance [11,22].

Another relevant aspect related to the screening for probiotic strains in autochthonous populations is the identification of species and the strains of potential candidates. The characterization at species level does not provide sufficient information to distinguish probiotics [23]. In this sense, the characterization of a potential probiotic isolate can be carried out by either nucleic acid or throughout cell activity assessment. The polymerase chain reaction (PCR)-based and 16S rRNA methods can be cited as relevant methods for the evaluation of nucleic acids of probiotic microorganisms [24].

Once the screening of isolates is complete and the probiotic strains are defined, the evaluation of these strains from the food technology point of view is necessary. In other words, the selected probiotic strains are used in the simplest strategy: starter cultures. The strategic selection of starter cultures consists on evaluating indicators: the fast and persistent colonization of meat mass, the production of organic acids (especially lactic acid), the inhibition of competitive microbiota (both spoilage and pathogenic microorganisms), prevailing at a reduced water activity (aw), and also preserving or 
enhancing the sensory attributes of fermented meat product [25]. Taking into account the relevant and increasing information published recently about the role of autochthonous probiotic microorganism found in meat products, this review aims to discuss the selection, identification, and evaluation as starter culture of meat products autochthonous microorganisms.

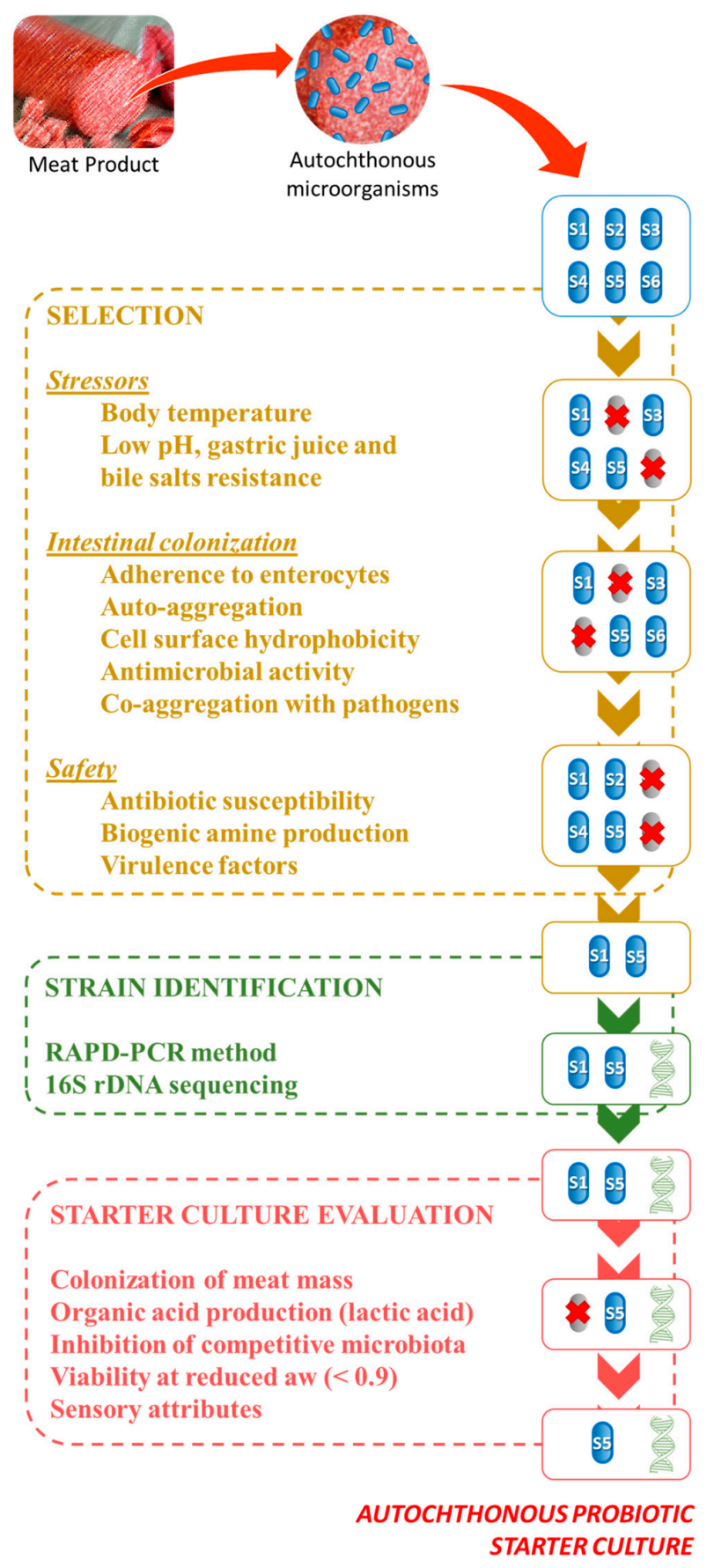

Figure 1. Schematic representation of the selection, identification, and evaluation of starter culture potential of meat products autochthonous microorganisms.

\section{Characterization of Autochthonous Probiotics Found in Meat Products}

\subsection{Selection Criteria for Probiotic Strains}

The selection of probiotic microorganisms takes into account the stressor and the expected effect during digestion and colonization of gut. The criteria to select probiotic microorganisms 
comprises multiple aspects that include the influence of digestion on viability, metabolism, and growth; the adherence to enterocytes; the capacity to inhibit competitive microbiota (especially pathogenic bacteria); the low harmful potential (virulence factors and biosynthesis of biogenic amines, for instance); and the susceptibility to antibiotics of isolated strains [11,23].

Regarding the potential probiotic microorganism naturally found in meat products, recent studies characterize promising candidates (Table 1). The capacity to prevail under unfavorable conditions such as those imposed by digestion is the first criterion to select probiotic strains. For instance, the evaluation $42 \mathrm{LAB}$ isolated from Ciauscolo salami (traditional Italian fermented sausage) indicated most strains were capable to survive to low $\mathrm{pH}$ and bile salts [26]. The authors indicated that Pediococcus pentosaceus 62781-3, 46035-1, 46035-4 and Leuconostoc mesenteroides 14324-8 strains were capable to resist hydrochloric acid ( $\mathrm{pH}$ 2.5) or bile salts ( $\mathrm{pH}$ 7.2) for $3 \mathrm{~h}$ in MRS broth.

In a related experiment with Harbin dry sausages (traditional Chinese fermented sausage), four isolates (P. pentosaceus R1, Lactobacillus brevis R4, Lactobacillus curvatus R5, and Lactobacillus fermentum R6) were evaluated regarding the capacity to survive simulated gastric digestion in stomach ( $\mathrm{pH}$ 3.0) and gut ( $\mathrm{pH}$ 8.0) [27]. The isolates L. brevis $\mathrm{R} 4$ and L. fermentum $\mathrm{R} 6$ displayed the highest survival rates for digestion in both stomach and gut. Likewise, two strains of Lactobacillus plantarum (CB9 and CB10) were selected from the natural microbial community of cured beef because of their capacity to survive after being exposed to $\mathrm{pH} 2.0$ and bile salts [28]. A similar outcome was reported for Enterococcus faecium 120 that displayed both acidic and bile salt resistance in simulated gastric juice [29].

A recent study evaluated the acidic and bile resistance of five LAB isolates (Lactococcus lactis subsp. cremoris CTCa 204, L. lactis subsp. hordiniae CTC 483, L. lactis subsp. cremoris CTC 484, L. plantarum CTC 368, and L. plantarum CTC 469) obtained from different meat products [30]. Although all strains were resistant to an acidic environment (on pH 1-5 for up $3 \mathrm{~h}$ ), the same effect was not observed for bile salt test wherein all strains were sensible to both bile salt concentration (from 0.1 to $2.0 \%$ ) and exposure time (up to $3 \mathrm{~h}$ ). Similarly, the study carried out by Petrović et al. [31] evaluated 21 E. faecium isolates regarding the capacity to prevail in low-pH medium and with bile salts in simulated gastric juice. According to authors, all the strains presented acid tolerance but only two strains (sk7-5 and sk9-15) were resistant to bile salts. In a recent study, the resistance of Pediococcus acidilactici CE51 (isolated from a meat sausage) to low $\mathrm{pH}$ and bile salts was evaluated [32]. The authors indicated that this isolate was resistant to acid ( $\mathrm{pH} 2.0,2.5$, and 3.5) but it was affected by bile salts $(0.9 \%)$. A related experiment indicated that Staphylococcus sp. DBOCP6 (isolated from fermented meat products) displayed capacity to resist the stress induced by gastrointestinal digestion [33].

The study carried out by Klayraung et al. [34] observed that 36 and 66 strains (from a total of 169 isolates from different Lactobacillus spp.) were resistant to acid and bile salts, respectively. A related experiment with isolates from pork sausages indicated that most of 32 Lactobacillus spp. strains displayed potential to survive the digestion and reach the intestine (survival rate $>90 \%$ ) [35]. In the same line of research, the experiment carried out by Topçu, Kaya, and Kaban [36] with isolates from traditionally produced Pastırma indicated that all P. pentosaceus strains (K7, K41, K44, K51, and K81) and P. acidilactici $\mathrm{K} 99$ were capable to resist simulated gastric and intestinal fluid.

Yuksekdag and Aslim [37] investigated the natural microbial community in Sucuk for potential probiotics. Among the selected isolates, P. pentosaceus Z12P and Z13P strains displayed the highest capacity to resist the impact of low $\mathrm{pH}$ and bile salts. In a related experiment, Zommiti et al. [38] carried out a similar experiment with E. faecium strains isolated from dried Ossban (a Tunisian fermented meat product). The five strains selected for probiotic evaluation displayed good potential to resist the stress imposed by low $\mathrm{pH}$ and bile. Scandinavian-type fermented sausages are also relevant sources of autochthonous probiotic as indicated by Klingberg et al. [39]. According to the authors, most of the isolated microorganisms (Lactobacillus spp. and P. pentosaceus) displayed potential to grow in acidic environment and in the presence of bile salts. 
Table 1. Autochthonous probiotic strains found in meat products.

\begin{tabular}{|c|c|c|c|c|}
\hline $\begin{array}{l}\text { Source of Probiotic } \\
\text { Microorganisms }\end{array}$ & Probiotic Selection Assays & Isolated Microorganisms & Potential Probiotics & Ref. \\
\hline $\begin{array}{l}\text { Ciauscolo salami (traditional } \\
\text { Italian fermented sausage) }\end{array}$ & $\begin{array}{l}\text { Resistance to low } \mathrm{pH} \text { and bile salts, cell } \\
\text { adhesion, and antibiotic resistance }\end{array}$ & $\begin{array}{l}42 \text { LAB }^{1} \text { isolates comprising: Carnobacterium } \\
\text { spp., Enterococcus faecalis, Lactobacillus brevis, } \\
\text { Lactobacillus casei, Lactobacillus johnsonii, } \\
\text { Lactococcus lactis, Lactobacillus paracasei, } \\
\text { Lactobacillus paraplantarum, Lactobacillus sakei, } \\
\text { Lactococcus spp, Leuconostoc mesenteroides, } \\
\text { Pediococcus pentosaceus, and Weissella hellenica } \\
\text { strains }\end{array}$ & $\begin{array}{c}\text { P. pentosaceus } 62781-3,46035-1, \\
\text { and } 46035-4 \text {, and } L . \\
\text { mesenteroides } 14324-8\end{array}$ & [26] \\
\hline $\begin{array}{l}\text { Traditional Portuguese } \\
\text { fermented meat products }\end{array}$ & $\begin{array}{l}\text { Resistance to low } \mathrm{pH} \text {, bile salts, and } \\
\text { body temperature; antimicrobial } \\
\text { activity; and biogenic amine production }\end{array}$ & Enterococcus faecium 85, 101, 119, and 120 & E. faecium 120 & [29] \\
\hline $\begin{array}{l}\text { Harbin dry sausages (traditional } \\
\text { Chinese fermented sausage) }\end{array}$ & $\begin{array}{l}\text { Resistance to gastric transit and bile } \\
\text { salts, auto-aggregation, cell adhesion, } \\
\text { and hydrophobicity }\end{array}$ & $\begin{array}{l}\text { P. pentosaceus R1, Lactobacillus brevis R4, } \\
\text { Lactobacillus curvatus R5 and Lactobacillus } \\
\text { fermentum R6 }\end{array}$ & L. brevis $\mathrm{R} 4$ & {$[27]$} \\
\hline Meat products & $\begin{array}{l}\text { Resistance to low } \mathrm{pH} \text {, bile salts, and } \\
\text { body temperature; biofilm formation; } \\
\text { virulence factors; antibiotic resistance; } \\
\text { and biogenic amine production }\end{array}$ & $\begin{array}{l}\text { L. lactis subsp. cremoris CTCa 204, L. lactis } \\
\text { subsp. hordiniae CTC } 483 \text {, L. lactis subsp. } \\
\text { cremoris CTC 484, Lactobacillus plantarum CTC } \\
\text { 368, and L. plantarum CTC } 469\end{array}$ & $\begin{array}{l}\text { L. lactis CTC } 204 \text { and } L \text {. } \\
\text { plantarum CTC } 368 \text { strains }\end{array}$ & {$[30]$} \\
\hline Cured beef & $\begin{array}{l}\text { Resistance to low } \mathrm{pH} \text { and bile salts; } \\
\text { antimicrobial activity; auto- and } \\
\text { co-aggregation; cell adhesion and } \\
\text { hydrophobicity; hemolytic activity; and } \\
\text { antibiotic resistance }\end{array}$ & $\begin{array}{l}\text { L. plantarum (CB9 and CB10) and Weissella } \\
\text { cibaria CB12 }\end{array}$ & $\begin{array}{l}\text { L. plantarum } \mathrm{CB} 9 \text { and } \mathrm{CB} 10 \\
\text { strains }\end{array}$ & {$[28]$} \\
\hline $\begin{array}{l}\text { Sokobanja sausage (traditional } \\
\text { Serbian sausage) }\end{array}$ & $\begin{array}{l}\text { Resistance to simulated gastrointestinal } \\
\text { digestion; antimicrobial activity; } \\
\text { biogenic amine production; and } \\
\text { antibiotic resistance }\end{array}$ & $\begin{array}{l}\text { E. faecium sk6-1 and }-17 ; \text { sk7-5, } 7 \text { and } 8 ; \text { sk8-1, 2, } \\
\text { 4, 5, 7, 12, 13, } 17 \text { and } 20 ; \text { sk9-3, } 11 \text { and } 15 ; \\
\text { sk10-1, 7, } 10 \text { and } 12\end{array}$ & $\begin{array}{l}\text { E. faecium sk7-5, sk7-8 and } \\
\text { sk9-15 }\end{array}$ & {$[31]$} \\
\hline Meat sausage & $\begin{array}{l}\text { Resistance to low } \mathrm{pH} \text { and bile salts; } \\
\text { antimicrobial activity; and antibiotic } \\
\text { resistance }\end{array}$ & Pediococcus acidilactici CE51 & Suitable probiotic characteristics & {$[32]$} \\
\hline
\end{tabular}


Table 1. Cont.

\begin{tabular}{|c|c|c|c|c|}
\hline $\begin{array}{l}\text { Source of Probiotic } \\
\text { Microorganisms }\end{array}$ & Probiotic Selection Assays & Isolated Microorganisms & Potential Probiotics & Ref \\
\hline Fermented pork sausages & $\begin{array}{l}\text { Resistance to simulated } \\
\text { gastrointestinal digestion, cell } \\
\text { hydrophobicity, antimicrobial } \\
\text { activity, and antibiotic resistance }\end{array}$ & $\begin{array}{l}169 \text { Lactobacillus spp. strains (L. curvatus, } \\
\text { Lactobacillus reuteri, L. plantarum, Lactobacillus } \\
\text { parapentarum, L. pentosus, Lactobacillus keferi, } \\
\text { L. fermentum, Lactobacillus animalis, Lactobacillus } \\
\text { mucosae, Lactobacillus aviaries ssp. aviaries, } \\
\text { L. salivarius ssp. salicinus, L. salivarius ssp. } \\
\text { salivarius, Lactobacillus hilgardii, } \\
\text { and Lactobacillus panis) }\end{array}$ & $\begin{array}{l}\text { L. fermentum } 3007 \text { and } \\
\quad 3010 \text { strains }\end{array}$ & {$[34]$} \\
\hline Pork sausages & $\begin{array}{l}\text { Resistance to simulated gastrointestinal } \\
\text { digestion, cell hydrophobicity, } \\
\text { auto- and co-aggregation, hemolytic } \\
\text { activity, biogenic amine production, } \\
\text { and antibiotic resistance }\end{array}$ & 32 Lactobacillus spp. strains & $\begin{array}{l}\text { L. plantarum UFLA SAU } 14,20, \\
34,52,91,172,185,187,238, \\
\text { and } 258\end{array}$ & {$[35]$} \\
\hline $\begin{array}{l}\text { Pastırma (Turkish cured } \\
\text { beef product) }\end{array}$ & $\begin{array}{l}\text { Resistance to simulated gastrointestinal } \\
\text { digestion, cell hydrophobicity, } \\
\text { auto- and co-aggregation, } \\
\text { and cell adhesion }\end{array}$ & $\begin{array}{l}\text { P. pentosaceus K7, K41, K44, K51, and } \mathrm{K} 81 \text { and } \\
\text { P. acidilactici } \mathrm{K} 99\end{array}$ & $\begin{array}{l}\text { P. pentosaceus } \mathrm{K} 41 \text { and } \mathrm{K} 44 \text { and } \\
\text { P. acidilactici } \mathrm{K} 99\end{array}$ & {$[36]$} \\
\hline $\begin{array}{l}\text { Sucuk (Turkish } \\
\text { fermented sausage) }\end{array}$ & $\begin{array}{l}\text { Resistance to simulated gastrointestinal } \\
\text { digestion, antimicrobial activity, } \\
\text { auto- and co-aggregation, } \\
\text { and antibiotic resistance }\end{array}$ & $\begin{array}{l}\text { P. pentosaceus Z9P, Z12P, and Z13P, P. acidilactici } \\
\text { Z10P, and P. dextrinicus Z11P }\end{array}$ & P. pentosaceus Z12P and Z13P & {$[37]$} \\
\hline $\begin{array}{l}\text { Dried Ossban (Tunisian } \\
\text { fermented meat product) }\end{array}$ & $\begin{array}{l}\text { Resistance to simulated gastrointestinal } \\
\text { digestion, auto-aggregation, } \\
\text { cell adhesion, virulence factors, } \\
\text { biogenic amine production, bacteriocin } \\
\text { production, antimicrobial activity, } \\
\text { and antibiotic resistance }\end{array}$ & $\begin{array}{l}\text { E. faecium strains MZF1, MZF2, MZF3, MZF4, } \\
\text { and MZF5 }\end{array}$ & All strains & {$[38]$} \\
\hline $\begin{array}{l}\text { Scandinavian-type } \\
\text { fermented sausages }\end{array}$ & $\begin{array}{l}\text { Resistance to simulated gastrointestinal } \\
\text { digestion, cell adhesion, } \\
\text { and antimicrobial activity }\end{array}$ & $\begin{array}{l}\text { Lactobacillus alimentarius MF1297, Lactobacillus } \\
\text { farciminis DC11 and MF1288, Lactobacillus } \\
\text { pentosus MF1300, L. plantarum DC13, MF1291, } \\
\text { MF1298, Lactobacillus rhamnosus DC8, L. sakei } \\
\text { MF1295, MF1296, Lactobacillus salivarius DC2, } \\
\text { DC4, DC5, and P. pentosaceus DC12 }\end{array}$ & $\begin{array}{l}\text { L. pentosus MF1300 and } \\
\text { L. plantarum MF1291 and } \\
\text { MF1298 strains }\end{array}$ & {$[39]$} \\
\hline
\end{tabular}


Table 1. Cont.

\begin{tabular}{|c|c|c|c|c|}
\hline $\begin{array}{l}\text { Source of Probiotic } \\
\text { Microorganisms }\end{array}$ & Probiotic Selection Assays & Isolated Microorganisms & Potential Probiotics & Ref. \\
\hline Spanish dry-cured sausages & $\begin{array}{l}\text { Resistance to simulated intestinal } \\
\text { digestion, biofilm formation; virulence } \\
\text { factors, biogenic amine production, and } \\
\text { antibiotic resistance }\end{array}$ & $\begin{array}{l}46 \text { LAB strains (E. faecium, Lactobacillus } \\
\text { coryniformis, L. paracasei, L. plantarum, } \\
\text { and L. sakei) }\end{array}$ & $\begin{array}{l}\text { L. paracasei } \mathrm{Al}-128 \text { and } \\
\text { L. sakei } \mathrm{Al}-143\end{array}$ & {$[40]$} \\
\hline $\begin{array}{l}\text { Slavonski kulen sausage } \\
\text { (traditional Croatian sausage) }\end{array}$ & $\begin{array}{l}\text { Resistance to simulated intestinal } \\
\text { digestion, antimicrobial activity, } \\
\text { enterotoxin production, and antibiotic } \\
\text { resistance }\end{array}$ & $\begin{array}{l}\text { L. plantarum } 1 \mathrm{~K}, \text { L. delbrueckii } 2 \mathrm{~K}, \\
\text { L. mesenteroides } 6 \mathrm{~K} 1 \text {, L. acidophilus } 7 \mathrm{~K} 2, \\
\text { S. xylosus } 4 \mathrm{~K} 1, \text { S. warneri } 3 \mathrm{~K} 1, \text { S. lentus } 6 \mathrm{~K} 2 \text {, } \\
\text { and S. auricularis } 7 \mathrm{~K} 1\end{array}$ & $\begin{array}{l}\text { All LAB and S. xylosus } 4 \mathrm{~K} 1 \text {, } \\
\text { S. warneri } 3 \mathrm{~K} 1 \text { strains }\end{array}$ & [41] \\
\hline Slovak traditional sausages & $\begin{array}{l}\text { Resistance to simulated intestinal } \\
\text { digestion, antimicrobial activity, } \\
\text { bacteriocin production, cell adhesion, } \\
\text { biogenic amine production, } \\
\text { and antibiotic resistance }\end{array}$ & S. xylosus and S. carnosus strains & S. $x y l o s u s \mathrm{SO} / 1 \mathrm{M} / 1 / 2$ & {$[42]$} \\
\hline Indian fermented meat & $\begin{array}{l}\text { Resistance to simulated gastrointestinal } \\
\text { digestion, cell hydrophobicity, } \\
\text { auto-aggregation, antimicrobial activity, } \\
\text { hemolytic activity, and } \\
\text { antibiotic resistance }\end{array}$ & Staphylococcus sp. DBOCP6 & Suitable probiotic characteristics & {$[33]$} \\
\hline Fermented meat products & $\begin{array}{l}\text { Resistance to simulated gastrointestinal } \\
\text { digestion, hemolytic activity, } \\
\text { cell adhesion, cholesterol-lowering } \\
\text { property, and antibiotic resistance }\end{array}$ & $12 \gamma$-aminobutyric acid-producing strains & $\begin{array}{l}\text { P. pentosaceus } \mathrm{HN} 8 \text { and } \\
\text { L. namurensis } \mathrm{NH} 2\end{array}$ & [43] \\
\hline Vienna sausages & $\begin{array}{l}\text { Resistance to simulated gastrointestinal } \\
\text { digestion, cell hydrophobicity, cell } \\
\text { adhesion, auto- and co-aggregation, } \\
\text { and antibiotic resistance }\end{array}$ & $\begin{array}{l}\text { E. faecium UAM1, UAM2, UAM3, UAM4, } \\
\text { UAM5, and UAM6 }\end{array}$ & E. faecium UAM1 & {$[44]$} \\
\hline Iberian dry fermented sausages & $\begin{array}{l}\text { Resistance to simulated } \\
\text { gastrointestinal digestion }\end{array}$ & $\begin{array}{l}15 \text { LAB and bifidobacteria strains (Lactobacillus } \\
\text { spp., Bifidobacteria spp., Lactococcus spp., } \\
\text { and Enterococcus spp.) }\end{array}$ & $\begin{array}{c}\text { P. acidilactici KKA and } \\
\text { UGA146-3 and E. faecium CICC } \\
\text { 6078, CK1013, and IDCC } 2102\end{array}$ & [45] \\
\hline
\end{tabular}


Table 1. Cont.

\begin{tabular}{|c|c|c|c|c|}
\hline $\begin{array}{l}\text { Source of Probiotic } \\
\text { Microorganisms }\end{array}$ & Probiotic Selection Assays & Isolated Microorganisms & Potential Probiotics & Ref. \\
\hline $\begin{array}{c}\text { Traditional dry } \\
\text { fermented sausages }\end{array}$ & $\begin{array}{l}\text { Resistance to simulated } \\
\text { gastrointestinal digestion }\end{array}$ & 20 Lactobacillus spp. strains & $\begin{array}{l}\text { L. brevis AY318799, AY318801, } \\
\text { and AY318804, L. curvatus } \\
\text { AY318826, L. fermentum } \\
\text { AY318825, L. paracasei ssp. } \\
\text { paracasei AY318806, AY318809, } \\
\text { and AY318824, and } \\
\text { L. plantarum AY318822 }\end{array}$ & [46] \\
\hline
\end{tabular}

${ }^{1}$ LAB: lactic acid bacteria. 
Landeta et al. [40] reported that isolated L. sakei strains were more resistant to bile salts than E. faecium strains (all obtained from Spanish dry-cured sausages). Moreover, the authors also observed that L. plantarum AI-122 and AI-148 strains were the most resistant among all isolates. In a similar way, Babić et al. [41] investigated the microbiota of Slavonski kulen sausage for potential probiotics. According to the authors, the four isolated LAB (L. plantarum $1 \mathrm{~K}$, L. delbrueckii $2 \mathrm{~K}$, L. mesenteroides 6K1, and L. acidophilus 7K2) and two strains of Staphylococcus (S. xylosus 4K1 and S. warneri 3K1) displayed capacity to resist the action of bile salts.

Isolates (S. xylosus and S.carnosus) with capacity to resist the stress imposed by bile salts were also reported in Slovak traditional sausages [42]. The authors of this study indicated that the ability to survive varied between 54 and 99\%. Likewise, Ruiz-Moyano et al. [45] observed that among the 15 isolated microorganisms from Iberian dry fermented sausages $P$. acidilactici KKA and UGA146-3 and E. faecium CICC 6078, CK1013, and IDCC 2102 displayed potential to grow after a simulated gastrointestinal digestion.

An interesting study was carried out by Ratanaburee et al. [43] by selecting autochthonous LAB strains from fermented meat products with $\gamma$-amino butyric acid production (a compound associated with the regulation of diabetes, mental illness, and autonomic disorders). According to the authors, four selected strains (P. pentosaceus HN8, NH102, NH116, and Lactobacillus namurensis NH2) out of 14 isolates displayed potential to produce $\gamma$-amino butyric acid and be potentially used as probiotics. The authors of this study indicated that the four isolated probiotics were capable to resist the simulated gastrointestinal digestion assay.

It is worth mentioning that the influence of body temperature in the viability of potential probiotic strains was also tested. Barbosa et al. [29] indicated that non-significant effects were observed for the viability of E. faecium $85,101,119$, and 120 counts for $120 \mathrm{~min}$ at $37^{\circ} \mathrm{C}$. In a similar way, Moreno et al. [30] showed that L. lactis subsp. cremoris CTC 204, L. lactis subsp. hordiniae CTC 483, L. lactis subsp. cremoris CTC 484, L. plantarum CTC 368, and L. plantarum CTC 469 can grow at $37^{\circ} \mathrm{C}$. Klingberg et al. [39] indicated that most of the isolates from Scandinavian-type fermented sausages displayed potential to grow at $37^{\circ} \mathrm{C}$ after being freeze-dried.

Once the probiotics reach the gut, the capacity to adhere to enterocytes, auto-aggregation, as well as the high cell surface hydrophobicity are essential to improve the chances of successful colonization in small intestine. In this sense, many recent studies with isolates from meat products evaluated this crucial characteristic of probiotics. The study carried out by Wang et al. [28] was a valid example of this characterization. The strains L. plantarum CB9 and CB10 displayed higher capacity to adhere to the surface of SW480 cells than the Weissella cibaria CB12. A similar outcome was also obtained for hydrophobicity and auto-aggregation tests. Similarly, Topçu et al. [36] observed that the P. pentosaceus K7, K41, K44, K51, and K81 and P. acidilactici K99 displayed the higher values in the hydrophobicity, auto-aggregation, and cell adhesion assays from the microorganisms naturally found in pastırma. Regarding the isolates from Harbin dry sausages [27], L. brevis R4 was the isolate with the highest percentage in auto-aggregation, cell adhesion, and surface hydrophobicity assays. Another related study performed by Borah et al. [33] with Staphylococcus sp. DBOCP6 indicated that this bacterium displayed suitable levels of hydrophobicity and auto-aggregation. Contrastingly, in the experiment carried out by Dias et al. [35], the isolated LAB strains had intermediate cell hydrophobicity and auto-aggregation.

It is relevant to mention that these probiotic characteristics can vary among strains. This outcome was reported by Zommiti et al. [38]. These authors obtained the differences in the auto-aggregation and cell adhesion capacities of E. faecium strains isolated from Dried Ossban. While the MZF1 and MZF2 strains had the highest auto-aggregation capacity, the highest cell adhesion index was obtained from MZF5 strain. In a similar way, significant differences in the hydrophobic potential among isolated strains from fermented meat products were indicated by Ratanaburee et al. [43]. According to the authors, P. pentosaceus HN8 displayed the highest hydrophobic potential in comparison to other isolated strains P. pentosaceus NH102 and NH116 and L. namurensis NH2. 
In another related study, the variation in the capacity to adhere to Caco-2 cells was obtained among 42 LAB isolates [26]. Most of the 42 isolates displayed weak or medium capacity to adhere to cell surface, except for Enterococcus faecalis 18156-3 and L. casei 12668-1. In the same line of thought, Klingberg et al. [39] observed that significant differences were observed among isolated microorganisms from Scandinavian-type fermented sausages. The strains P. pentosaceus DC12 and L. salivarius DC5 (isolated from Salami-type sausage and poultry salami, respectively) displayed the highest adhesion capacities while L. farciminis DC11 (isolated from a Salami-type sausage) displayed the lowest adhesion capacity. Another relevant example of the differences observed in the adhesion capacity among the isolated microorganisms from traditionally produced meat products was reported by Simonová et al. [42]. According to the authors, the strain with the highest adhesion index was S. carnosus $\mathrm{SO} 2 / \mathrm{F} / 2 / 5$. Conversely, this study also indicated that the strains $S$. xylosus SO1/1M/2b and SO2/2M/2a showed minimal adhesion capacities. Additionally, the study carried out by Klayraung et al. [34] with three isolates of L. fermentum from fermented pork sausages indicated that the strain 3007 had the highest hydrophobicity index in comparison to the 2311 and 3010 strains.

In a recent study, the biofilm formation capacity of five LAB isolates was evaluated [30]. In this study, the authors observed that all strains formed biofilms and the highest capacity was reported for L. lactis subsp. cremoris CTC204. Moreover, this strain displayed the highest response to $\mathrm{MgSO}_{4}(\mathrm{a}$ factor involved in the stimulation of microbial enzyme activity and growth) in the culture medium. The capacity to produce biofilm was also evaluated by Landeta et al. [40] in LAB isolated from Spanish dry-cured sausages. According to the authors, L. sakei strains (Al-109, Al-112, Al-113, and Al-115, for instance) displayed the capacity to produce biofilm as well as other isolated LAB such as L. coryniformis Al-127 and L. paracasei Al-120.

The capacity to inhibit the growth of pathogenic bacteria is another relevant probiotic activity. In this sense, the evaluation of antimicrobial potential as well as the co-aggregation capacity has been evaluated to select the probiotic strains from meat products. For instance, E. faecium 120 was the strain with the highest antimicrobial activity against the pathogens Listeria monocytogenes 7946 and 7947 , E. faecalis ATCC 29212 and DSMZ 13590, L. innocua 2030c and NTCT 11286, and Staphylococcus aureus ATCC 29213 [29]. Additionally, the authors indicated that the most probable mechanism to explain this strong effect in comparison to other isolates was due to the production of a bacteriocin.

The evaluation of antimicrobial activity of autochthonous E. faecium isolates found in Sokobanja sausage (traditional Serbian sausage) revealed that most of the strains displayed an inhibitory effect against Pseudomonas spp., Proteus spp., and Escherichia coli [31]. Conversely, the effect in Enterobacter spp. and L. monocitogenes was strain-dependent wherein intense inhibitory effects were obtained from strain sk8-4 and sk8-5, for instance. A similar outcome was reported by Zommiti et al. [38] who observed that all isolated E. faecium strains displayed high antimicrobial activity against Listeria innocua HPB13 and Enterococcus faecalis ATCC 29212, especially strains MZF1 and MZF5. According to the authors, one of the possible explanations for this effect can be related to the production of bacteriocin (Enterocin A, B, and P). However, none of the isolates displayed potential to inhibit the growth of S. aureus ATCC 25923, E. coli DH5a, P. aeruginosa PAO1, and S. typhimurium ATCC 14028. The experiment carried out by Klingberg et al. [39] also indicated the strain-dependent effect in the antimicrobial activity of probiotics isolated from meat products. In this study, the authors observed that L. plantarum MF1291 displayed antimicrobial activity against Bacillus cereus, Escherichia coli, Listeria monocytogenes, Salmonella typhimurium, Shigella flexneri, and Yersinia enterocolitica; however, the same antimicrobial activity was not observed for L. plantarum DC13. Moreover, L. pentosus MF1300, L. plantarum/pentosus MF1290, and L. salivarius DC5 were also strains with antimicrobial activity against these pathogenic bacteria.

The Pediococcus spp. strains isolated by Yuksekdag et al. [37] also displayed different antimicrobial activity against the L. monocytogenes, E. coli O-157:H7, and Micrococcus flavus. Although all Pediococcus strains inhibit the growth of L. monocytogenes, the inhibition of E. coli O-157:H7 growth was observed with two strains: Pediococcus Z9P and Z10P. Additionally, only Pediococcus Z13P was capable to inhibit the growth of $M$. flavus. A similar outcome was reported by Simonová et al. [42] who studied the 
antimicrobial activity of bacteriocins produced by S. xylosus and S.carnosus strains from a Slovak traditional sausages. According to the authors, the inhibitory effect of bacteriocins produced by all strains was observed against Enterococcus avium EA5 and Pseudomonas sp. SO1/1M/1/4 but only the bacteriocins produced by S. xylosus $\mathrm{SO} / 1 \mathrm{M} / 1 / 2$ and $S$. carnosus $\mathrm{SO} / \mathrm{F} / 2 / 5$ inhibited the growth of L. innoсиа LMG13568.

Babić et al. [41] reported that L. plantarum $1 \mathrm{~K}$, L. delbrueckii $2 \mathrm{~K}$, L. mesenteroides 6K1, and L. acidophilus 7K2 inhibited the growth of E. coli 3014 but a strain-dependent effect was observed for Staphylococcus spp. isolates. In this case, the strains S. warneri 3K1, S. xylosus 4K1, and S. lentus $6 \mathrm{~K} 2$ prevented the growth of E. coli 3014 whereas the strain S. auricularis 7K1 had a slight inhibitory effect. The selected L. fermentum strains obtained from fermented pork sausages displayed potential to inhibit the growth of S. aureus TISTR 029, E. coli TISTR 780, and Salmonella typhi DMST 5784 [34]. Likewise, the study performed by Borah et al. [33] indicated that Staphylococcus sp. DBOCP6 inhibited the growth of E. coli MTCC40.

In the study carried out by Vieira et al. [32], the antimicrobial activity of P. acidilactici CE51 was evaluated against L. monocytogenes ATCC 19015. Moreover, the authors indicated that this effect was attributed to a bacteriocin produced by P. acidilactici CE51 after neutralizing and heating ( $5 \mathrm{~min}$ at $95^{\circ} \mathrm{C}$ ) the supernatant of fermentation broth of this bacteria.

Another relevant aspect related to the expected antimicrobial activity of probiotics is the co-aggregation with pathogenic microorganisms with eventual elimination in the feces. This aspect was evaluated by Wang et al. [28] for L. plantarum CB9 and CB10 and W. cibaria CB12 with S. aureus ATCC 25923, Salmonella enterica ATCC 13076, E. coli ATCC 25922, and Shigella dysenteriae ATCC 13313. Different from that observed for auto-aggregation, the co-aggregation of isolates was strain-dependent for S. aureus (with L. plantarum CB9) and S. enterica (with L. plantarum CB9 and CB10). Additionally, a similar co-aggregation capacity of E. coli and S. dysenteriae was reported for the three isolated strains.

In a similar way, the P. pentosaceus strains isolated from pastirma displayed different capacities to co-aggregate with E. coli ATCC 25922 [36]. The highest values were reported for P. pentosaceus K44 while P. pentosaceus K41 and P. pentosaceus K41 displayed lower co-aggregation capacities. Dias et al. [35] carried out a related experiment with 32 Lactobacillus spp. strains isolated from pork sausages and observed that most of these strains co-aggregated with E. coli, S. typhi, and L. monocytogenes. In the experiment carried out by Yuksekdag et al. [37], the co-aggregation of P. pentosaceus with L. monocytogenes ATCC 7644 was strain dependent. Although all strains displayed co-aggregated potential, the highest percentage value was obtained with Z13P strain.

Another interesting aspect related to antimicrobial activity of potential probiotics isolated from meat products is their capacity to produce exopolysaccharides that can inhibit the formation and also induce the disruption of biofilms formed by pathogenic bacteria. The effectiveness of these compounds in producing Leuconostoc citreum and L. mesenteroides was explored by Abid et al. [47]. According to the authors, the exopolysaccharides produced by both microorganisms were capable to inhibit the formation of biofilms from S. aureus ATCC 25923, E. coli 25922, and E. faecalis 25912. Moreover, all potential probiotic strains also disrupted the biofilms formed by these pathogenic bacteria but at different degrees: E. coli 25922 and E. faecalis 25912 were more resistant to the exopolysaccharides produced by L. citreum and L. mesenteroides whereas S. aureus ATCC 25923 was more susceptible to these compounds.

Another decisive characteristic to select autochthonous strains as probiotic is their safety when these microorganisms are introduced in the diet and do not cause an infection. In this sense, the antibiotic susceptibility of potential probiotics was evaluated by many studies with autochthonous microorganisms isolated from meat products (Table 1). The study performed by Federici et al. [26] evaluated the antibiotic resistance of $42 \mathrm{LAB}$ isolates and revealed differences among species and strains. On the one hand, L. plantarum 9202-3 and Lactobacillus ssp. sakei 9202-6 were sensible to ampicillin, clindamycin, chloramphenicol, erythromycin, gentamycin, and tetracycline. On the other hand, the P. pentosaceus 12971-2 and 60211-2, P. pentosaceus 60211-2, Lactobacillus paraplantarum 35156-5 and 
Lactobacillus johnsonii 35156-2 were resistant to several of the tested antibiotics. It is important mentioning that few of these isolates displayed genes related to antibiotic resistance. A related experiment with Lactobacillus isolates displayed a similar outcome in terms of antibiotic resistance among strains [35]. Most of the isolated Lactobacillus strains were resistant to ampicillin, chloramphenicol, and gentamicin whereas almost all strains were susceptible to erythromycin. Similarly, the experiment performed by Ratanaburee et al. [43] also indicated that P. pentosaceus HN8, NH102, NH116, and Lactobacillus namurensis NH2 were susceptible to cefoperazone, cephalothin, chloramphenicol, erythromycin, and penicillin G. However, these authors also observed that the isolated strains were resistant to ceftazidime, gentamycin, kanamycin, norfloxacin, polymyxin B, streptomycin, and vancomycin.

In a related experiment, Moreno et al. [30] indicated that the resistance to antibiotics on strains isolated from Brazilian meat products was strain-dependent. The authors indicated that L. lactis CTC 204 was the most sensible to erythromycin, clindamycin, tetracycline, vancomycin, and amoxicillin. Likewise, the evaluation of antibiotic resistance of potential probiotics isolated from cured beef revealed that L. plantarum (CB9 and CB10) strains were sensible to ampicillin, tetracycline, chloramphenicol, erythromycin, roxithromycin, and lincomycin [28]. Conversely, W. cibaria CB12 displayed resistance to several antibiotics.

The experiment carried out by Landeta et al. [40] indicated that the resistance of LAB isolated from Spanish dry-cured sausages to antibiotics was species- and strain-dependent. Regarding the differences among species, several E. faecium were resistant to penicillin $G$ and tetracycline whereas many L. casei were susceptible to these antibiotics. In the case of strain susceptibility, the L. casei Al-123 and Al-144 were resistant to tetracycline whereas L. casei Al-125, Al-134, and Al-139 were susceptible to this antibiotic. A similar outcome was reported for L. fermentum isolated from Fermented pork sausages [34]. While the strains 2311 and 3010 were resistant to ampicillin, gentamycin, and trimethoprim, the strain 3007 was susceptible to these antibiotics. It is also relevant to mention that these three strains were susceptible to erythromycin, kanamycin, quinipristin, rifampicin, streptomycin, and tetracycline.

Babić et al. [41] evaluated the antibiotic resistance of isolated bacteria from Slavonski kulen sausage and noticed that L. acidophilus $7 \mathrm{~K} 2$, L. delbrueckii $2 \mathrm{~K}$, L. mesenteroides $6 \mathrm{~K} 1$, L. plantarum 1 $\mathrm{K}, \mathrm{S}$. warneri $3 \mathrm{~K} 1$, and $S$. xylosus $4 \mathrm{~K} 1$ were susceptible to erythromycin, gentamycin, and neomycin. Conversely, the strains S. lentus $6 \mathrm{~K} 2$ and S. auricularis 7K1 were resistant to at least one of these antibiotics. The study performed by Yuksekdag et al. [37] also indicated differences in the susceptibility to antibiotics among P. pentosaceus strains. While the isolates Z9P, Z10P, and Z11P were susceptible to penicillin and ampicillin, the strains Z12P and Z13P were resistant to these antibiotics. It is also important to mention that all strains were susceptible to at least four antibiotics.

In the case of E. faecium strains isolated from Sokobanja sausage, all strains (except for sk8-1 and sk8-17) displayed low resistance to the amoxicillin, cefalexin, ceftriaxone, erythromycin, ofloxacin, penicillin, and tetracycline [31]. A related experiment carried out by Simonová et al. [42] indicated that all isolated LAB from Slovak traditional sausages were susceptible or had minimal resistance to amoxicillin, ampicillin, chloramphenicol, clindamycin, erythromycin, gentamycin, lincomycin, methicilin, neomycin, novobiocin, rifampicin, tetracycline, tobramycin, and vancomycin. Similarly, the E. faecium strains MZF1, MZF2, MZF3, MZF4, and MZF5 studied by Zommiti et al. [38] were susceptible to ampicillin, chloramphenicol, gentamicin, tetracycline, and vancomycin. Likewise, Borah et al. [33] indicated that Staphylococcus sp. DBOCP6 isolated from Indian fermented meat was susceptible to ampicillin, ciprofloxacin, clindamycin, erythromycin, gentamicin, kanamycin, tetracycline, and vancomycin. Additionally, the evaluation of antibiotic resistance of $P$. acidilactici CE51 to different antibiotics revealed that the isolate was susceptible to ceftazidime, clindamycin, erythromycin, oxacillin, penicillin $\mathrm{G}$, and tetracycline but was resistant to ciprofloxacin, gentamicin, and vancomycin [32].

The safety of a probiotic also involves aspects such as the production of biogenic amines, the presence of virulence factors and hemolytic activity. In this regard, the Moreno et al. [30] evaluated the biosynthesis of biogenic amines potential of Lactococcus spp. and Lactobacillus spp. isolates and 
observed that L. lactis subsp. cremoris CTC 204 and L. plantarum CTC 368 displayed the lowest levels of cadaverine, histamine, putrescine, spermidine, and spermine among all isolated strains. All autochthonous E. faecium strains evaluated by Petrović et al. [31] did not produce histidine. However, the strains sk8-1 and sk8-17 produced tyrosine. Similarly, none of the 46 LAB strains isolated by Landeta et al. [40] produced histamine, putrescine, or cadaverine but all E. faecium strains were producers of tyrosine. Additionally, a related experiment with S. xylosus strains obtained from Slovak traditional sausages indicated these isolates did not produce cadaverine, histamine, phenylethylamine, putrescine, tryptamine, and tyramine [42]. Conversely, the production of phenylethylamine, tryptamine, and tyramine was reported in the strain S. carnosus $\mathrm{SO} 2 / \mathrm{F} / 2 / 5$ from this study. The experiment carried out by Barbosa et al. [29] indicated that E. faecium strains 85, 101, 119, and 120 did not show amino acid decarboxylase activity. A similar lack of decarboxylase activity was reported by Dias et al. [35] for Lactobacillus spp. strains and by Zommiti et al. [38] for E. faecium strains.

Another relevant aspect related to the evaluation of safety is the presence of virulence factors. In this regard, the study performed by Moreno et al. [30] evaluated the thermonuclease, hemolytic, and gelatinase activities of Lactococcus spp. and Lactobacillus spp. isolates. According to authors, none of the selected strains had thermonuclease, hemolytic, and gelatinase activities. A similar outcome was reported by Wang et al. [28]. The L. plantarum (CB9 and CB10) and W. cibaria CB12 isolated from cured beef did not show hemolytic activity. Babić et al. [41] indicated that none of the isolated strains from Slavonski kulen sausage displayed enterotoxin activity.

In a related experiment with 46 LAB isolates, Landeta et al. [40] did not detect the presence of virulence factors among all LAB strains. Similarly, Dias et al. [35] observed that none of the Lactobacillus spp. strains isolated from pork sausages displayed hemolytic activity. The absence of hemolytic activity was also reported for P. pentosaceus and L. namurensis isolated from the fermented meat products studied by Ratanaburee et al. [43]. Likewise, the evaluation of hemolytic activity in Staphylococcus sp. DBOCP6 carried out by Borah et al. [33] did not indicate this isolated bacterium could be harmful. Conversely, the experiment carried out by Zommiti et al. [38] indicated that some E. faecium strains isolated from dried Ossban displayed virulence factors. According to the authors, the strains MZF2, MZF3, and MZF5 did not show virulence factors whereas virulence factors were detected in MZF1 and MZF4 strains.

Finally, it is also relevant to mention that thermotolerant probiotics can also be found in cooked meat products [44]. In this case, six E. faecium strains (UAM1, UAM2, UAM3, UAM4, UAM5, and UAM6) were isolated from Vienna sausages and only the UAM1 strain displayed probiotic potential.

The autochthonous LAB of meat products are the predominant group that better fits the requirement of probiotic selection criteria proposed by health authorities. Moreover, the presence of these microorganisms with high potential to be used as probiotics in the production of meat products strengthens the hypothesis that the autochthonous microbial population is a valuable source of probiotics for the production and development of functional meat products.

\subsection{Identification Probiotic Strains}

Along with the techniques used to characterize the probiotic activity of autochthonous strains from meat products, the identification at strain level is necessary to ensure the use of the exact microorganism [48]. For instance, Federici et al. [26] characterized the specific primers (D8635 and Coc) for the identification of $42 \mathrm{LAB}$ isolates using the RAPD-PCR method. This protocol was also applied in the identification of Lactobacillus spp. and Lactococcus spp. isolated from different meat products [30], LAB and Staphylococcus spp. in Slavonski kulen sausage [41], and LAB in Scandinavian-type fermented sausages [39].

The use of $16 \mathrm{~S}$ rDNA sequencing was also employed in the identification of P. pentosaceus R1, L. brevis R4, L. curvatus R5, and L. fermentum R6 isolated from Harbin dry sausages [27]. Likewise, this method was used by Wang et al. [28] for the identification of L. plantarum (CB9 and CB10) and W. cibaria CB12, by Petrović et al. [31] for E. faecium (sk6-1 and -17; sk7-5, 7 and 8; sk8-1, 2, 4, 5, 
7, 12, 13, 17 and 20; sk9-3, 11 and 15; sk10-1, 7, 10 and 12) isolates, and by Vieira et al. [32] for P. acidilactici CE51. Klayraung et al. [34], Dias et al. [35], and Pennacchia et al. [46] applied the 16S rDNA sequencing technique to identify Lactobacillus spp. isolated from different meat products. Similarly, LAB and bifidobacteria strains were identified using this technique by Landeta et al. [40], Ratanaburee et al. [43], and Ruiz-Moyano et al. [45]. The experiments carried out by Topçu et al. [36] and by Yuksekdag and Aslim [37] identified P. pentosaceus and P. acidilactici and P. dextrinicus at strain level as well as Hernández-Alcántara et al. [44] and for E. faecium strains. In the case of Staphylococcus spp., Simonová et al. [42] identified the probiotic strains of S. xylosus and S. carnosus. In the same line, Borah et al. [33] used the 16S rDNA sequencing method to identify Staphylococcus sp. DBOCP6. It is worth mentioning that Zommiti et al. [38] performed the identification of E. faecium strains using a matrix-assisted laser desorption ionization-time-of-flight mass spectrometry (MALDI-TOF MS).

\section{Application of Autochthonous Probiotics in Meat Products}

The use of autochthonous probiotic bacteria as starter cultures in the production of fermented meat products also complied with the technological requirements: tolerance to stressors (reduced aw, for instance), the production of desired compounds (such as lactic acid, peptides and volatile compounds), inhibition of competitive microbiota (especially pathogenic bacteria), the preservation or enhancement of expected sensory attributes, and the low capacity to produce toxic compounds (such as enterotoxins and biogenic amines) are the most relevant aspects to define the viability of starter culture [25,49-52].

Some recent studies have provided a detailed view of the influence and the role of autochthonous probiotic strains in the processing of fermented products (Table 2). The use of autochthonous probiotic bacteria displays successful colonization of meat mass at the beginning of processing (fermentation stage), which prevails throughout the processing. The rapid growth, in the beginning, is a decisive aspect related to the production of meat products with autochthonous probiotics strains and prevents the growth of other microorganisms. For instance, Campaniello et al. [53] indicated that the counts of probiotic L. plantarum 178 increased in the beginning of the ripening period (from 7 to $8 \log \mathrm{CFU} / \mathrm{g}$ ) and remained stable until the end of processing in a Sweet Calabrian salami. High counts of LAB in meat products at the end of processing were reported by other authors using autochthonous probiotic starter cultures such as L. plantarum IIA-2C12 [54], L. plantarum IIA-2C12, and Lactobacillus acidophilus IIA-2B4 [55], L. plantarum L125 [56], L. sakei 8416, and L. sakei 4413 [57], P. acidilactici SP979 [58], and with a mix of ten strains of L. plantarum [35].

Another relevant aspect of the microorganisms that grow along with LAB with major technological relevance is the coagulase-negative staphylococci group. These microorganisms are directly involved in the modification of color by reducing nitrate intro nitrite that will eventually be converted into NO and form the nitrosomyoglobin pigment (characteristic cured color of fermented meat products) [59]. The growth of staphylococci group during the processing of a Sweet Calabrian salami, along with autochthonous probiotic LAB, was reported by Campaniello et al. [53]. At the end of processing of each fermented meat product, the LAB populations were in the range of 7-10 log CFU/g. Similarly, Pavli et al. [56] reported Staphylococci (4-5 log CFU/g) group as one of the main microorganisms during the processing of pork fermented sausage. Consequently, characteristic color of fermented meat products (especially redness) can be improved. Particularly for the improvement of redness, L. plantarum IIA-2C12 and L. acidophilus IIA-2B4 increased this quality indicator in comparison to control (without starter culture) in fermented beef sausages [55].

Although there is no current consensus about the ideal probiotic load in meat products to ensure health benefits, probiotics in meat products prevail during storage. The study performed by Pavli et al. [56] indicated that counts of probiotic strain (L. plantarum L125) were above $6 \log$ CFU/g during 160 days of refrigerated storage either at 4 or $12{ }^{\circ} \mathrm{C}$. This result is an important outcome to strengthen the role of autochthonous probiotic strains in the production of fermented meat products by indicating the survival of probiotic strains after long storage periods. 
Table 2. Influence of probiotic strains as starter cultures in meat products.

\begin{tabular}{|c|c|c|c|c|}
\hline Probiotic Microorganisms & Meat Product & Inoculum Count and Processing Conditions & Influence on Meat Product Quality Indicators & Ref. \\
\hline L. plantarum 178 & Sweet Calabrian salami & $\begin{array}{l}10 \log \mathrm{CFU} / \mathrm{g} \text {; stewing stage for } 4 \mathrm{~h} \text { at } 22^{\circ} \mathrm{C} \text { and } \mathrm{RH} \text { of } 99 \% \text {; } \\
\text { drying stage for } 7 \mathrm{~h} \text { at } 22^{\circ} \mathrm{C} \text { and } \mathrm{RH} \text { of } 65 \% \text {; intermediate } \\
\text { drying/ripening stage for } 4 \text { days from } 20 \text { to } 15{ }^{\circ} \mathrm{C} \text {, and } \mathrm{RH} \\
\text { from } 67 \% \text { to } 73 \% \text {; first ripening stage for } 5 \text { days at } 15^{\circ} \mathrm{C} \text { and } \\
\mathrm{RH} \text { of } 71 \% \text {; second ripening stage for } 5 \text { days at } 13{ }^{\circ} \mathrm{C} \text { and } \mathrm{RH} \\
\text { of } 73 \% \text {, and final ripening/maturation stage for } 15 \text { days at } \\
12{ }^{\circ} \mathrm{C} \text { and } \mathrm{RH} \text { of } 75 \%\end{array}$ & $\begin{array}{l}\text { Increased LAB count; reduced } \mathrm{pH} \text {; inhibited } \\
\text { enterobacteria growth }\end{array}$ & [53] \\
\hline L. plantarum IIA-2C12 & Fermented lamb sausage & $\begin{array}{l}9 \log \mathrm{CFU} 1 / \mathrm{mL} \text {; drying for } 1 \text { day } 25^{\circ} \mathrm{C} \text {, cold smoking for } \\
3 \text { days at } 27^{\circ} \mathrm{C}\end{array}$ & $\begin{array}{l}\text { Reduced } \mathrm{pH}, \mathrm{aw}^{2} \text { and Escherichia coli count; } \\
\text { increased } \mathrm{LAB}{ }^{3} \text { count, acidity, lactic acid content, } \\
\text { and sensory acceptance }\end{array}$ & {$[54]$} \\
\hline $\begin{array}{l}\text { L. plantarum IIA-2C12 and } \\
\text { Lactobacillus acidophilus IIA-2B4 }\end{array}$ & Fermented beef sausage & $\begin{array}{l}9 \log \mathrm{CFU} / \mathrm{g} \text {; conditioning for } 24 \mathrm{~h} \text { at } 27-29^{\circ} \mathrm{C} \text { and } \mathrm{RH}^{4} \\
88-90 \% \text {, cold smoking (three times) for } 4 \mathrm{~h}(12 \mathrm{~h} \text { in total) at } \\
27-29^{\circ} \mathrm{C} \text {, and fermentation for } 24 \mathrm{~h} \text { at } \mathrm{RT}^{5}\end{array}$ & $\begin{array}{l}\text { Reduced } \mathrm{pH} \text {, lipid oxidation, hardness, } \\
\text { Staphylococcus aureus and E. coli counts; increased } \\
\text { acidity, color, LAB count and volatile compounds; } \\
\text { not meaningful changes on fatty acid profile, } \\
\text { aw and sensory attributes }\end{array}$ & [55] \\
\hline L. plantarum L125 & Pork fermented sausage & $8 \log \mathrm{CFU} / \mathrm{g}$; fermentation for 4 days; ripening for 8 days & $\begin{array}{l}\text { High counts of LAB and staphylococci; increased } \\
\text { redness, raw odor and acidic taste; reduced } \mathrm{pH} \\
\text { and aw; final product was microbiologically safe }\end{array}$ & [56] \\
\hline L. sakei 8416 and L. sakei 4413 & $\begin{array}{l}\text { Beef and pork } \\
\text { fermented sausage }\end{array}$ & $\begin{array}{l}7 \log \mathrm{CFU} / \mathrm{g} \text {; fermented for } 6 \text { days from } 20 \text { to } 15^{\circ} \mathrm{C}, \mathrm{RH} \text { from } \\
95 \text { to } 80 \% \text { and air velocity from } 0.7 \text { to } 0.5 \mathrm{~m} / \mathrm{s} \text {, smoked for } 3 \mathrm{~h} \text {; } \\
\text { ripened for } 21 \text { days at } 15^{\circ} \mathrm{C}, \mathrm{RH} 80 \% \text { and air velocity at } \\
0.05-0.1 \mathrm{~m} / \mathrm{s}\end{array}$ & $\begin{array}{l}\text { Increased LAB count; absence of L. monocytogenes } \\
\text { and presumptive } E \text {. coli O157; reduced } \mathrm{pH} \text { and aw }\end{array}$ & [57] \\
\hline Mix with 10 L. plantarum strains & Fermented pork sausage & $7 \log \mathrm{CFU} / \mathrm{g} ; 30$ days at $10^{\circ} \mathrm{C}$ & $\begin{array}{l}\text { Increased LAB count; reduced S. typhi and } \\
\text { L. monocytogenes counts, and } \mathrm{pH}\end{array}$ & [35] \\
\hline P. acidilactici SP979 & Spanish salchichón & $\begin{array}{l}7.5 \log \mathrm{CFU} / \mathrm{g} ; 10{ }^{\circ} \mathrm{C} \text { and } 80 \% \mathrm{RH} \text { for } 22 \text { days at } 12{ }^{\circ} \mathrm{C} \text { and } 70 \% \\
\mathrm{RH} \text { for } 26 \text { days }\end{array}$ & $\begin{array}{l}\text { Increased moisture and protein content; reduced } \\
\mathrm{pH} \text {, lipid content and oxidation, }\end{array}$ & {$[58]$} \\
\hline $\begin{array}{l}\text { P. pentosaceus } \mathrm{HN} 8 \text { and } \\
\text { L. namurensis } \mathrm{NH} 2\end{array}$ & $\begin{array}{l}\text { Thai fermented pork } \\
\text { sausage (Nham) }\end{array}$ & $6 \log \mathrm{CFU} / \mathrm{g}$ for each strain; fermented for 4 days & Reduced biogenic amines and cholesterol contents & [60] \\
\hline
\end{tabular}

${ }^{1} \mathrm{CFU}$ : colony forming unit; ${ }^{2}$ aw: water activity; ${ }^{3} \mathrm{LAB}$ : lactic acid bacteria; ${ }^{4} \mathrm{RH}$ : relative humidity; and ${ }^{5} \mathrm{RT}$ : room temperature. 
A characteristic effect of LAB growth in the fermentation of meat products is the gradual $\mathrm{pH}$ drop during processing due to the production of lactic acid. This characteristic effect was reported in recent studies (Table 2) with meat fermentation by autochthonous probiotic LAB, such as reported by [54] in lamb sausage fermented with L. plantarum IIA-2C12. In this study, the inoculation of autochthonous probiotic bacteria increased the content of lactic acid in comparison to non-inoculated sausage (3.0\% vs. $2.0 \%$, respectively). In accordance with this scenario, the $\mathrm{pH}$ of meat products fermented with autochthonous probiotic was reduced in comparison to fresh meat mass prior to fermentation stage.

This drop of $\mathrm{pH}$ occurred with the fermentation of a pork meat sausage with L. plantarum L125 wherein a drop from 6 to below 4.5 was seen [56]. Moreover, non-significant difference was indicated in comparison to control (using commercial starter culture with P. pentosaceus and Staphylococcus carnosus). Likewise, the similar low $\mathrm{pH}$ (between 4.1 and 5.5) in the final product was also reported with other fermented meat products [53,55,57]. Conversely the experiment carried out by Ruiz-Moyano et al. [58] indicated that the addition of P. acidilactici SP979 did not significantly alter the pH of Spanish salchichón (final $\mathrm{pH}$ around 6.0). Likewise, Dias [35] obtained a final $\mathrm{pH}$ of 5.7 in fermented pork sausage inoculated with a mix of $10 \mathrm{~L}$. plantarum strains after 30 days at $10{ }^{\circ} \mathrm{C}$.

Another aspect related to the successful colonization of autochthonous probiotic strains during the fermentation of meat products is the inhibition of competitive microbiota (natural and contaminating). In this sense, recent studies indicated a similar or improved capacity to inhibit the growth of pathogenic microorganisms. The inhibitory effect was reported for L. plantarum IIA-2C12 and L. acidophilus IIA-2B4 that inhibited the growth of E. coli, Salmonella spp., and S. aureus in fermented beef sausage [55]. A similar antimicrobial effect against pathogenic groups of microorganisms was reported by Campaniello et al. [53] during the processing of Sweet Calabrian salami. The authors observed that Enterobacteria counts were reduced to non-detectable levels during the processing as well as for Clostridia, E. coli, Salmonella sp., and L. monocytogenes. The study performed by Dias et al. [35] indicated a reduction in the counts of S. typhi and L. monocytogenes in 30 days at $10{ }^{\circ} \mathrm{C}$.

Likewise, Brochothrix spp., Enterobacteriaceae, L. monocytogenes, Pseudomonas spp., yeasts, and molds were below the detection limits in the pork sausages inoculated with L. plantarum L125 [56]. The experiment carried out by Pragalaki et al. [57] indicated the absence of L. monocytogenes and presumptive E. coli O157 in sausages elaborated with autochthonous probiotic strains L. sakei 8416 and L. sakei 4413 and in control (spontaneous fermentation) treatment. It is relevant mentioning that the outcomes reported in fermented meat products in relation to the antimicrobial activity are in accordance with the information indicated by the in vitro assays for the characterization of probiotic activity (Table 1).

Water activity (aw) is another important processing variable that influences the growth and metabolism of microorganisms in food, particularly when values below 0.9 are obtained during processing [61]. Although reaching this threshold is an important condition to inhibit the growth of spoilage and pathogenic microorganism and extend the shelf life of food, probiotic microorganisms are subjected to the same condition too. Differently than observed for other microorganisms, the selected autochthonous probiotic bacteria prevail in this condition and compose the majority of the microbial population in final products and during the storage period [56]. Other studies indicated a similar scenario where autochthonous probiotic strains (evaluated as LAB) were the main group of microorganisms: L. sakei 8416 and L. sakei 4413 at aw of 0.86 [55], L. plantarum 178 at aw <0.85 [53], L. sakei 8416 and L. sakei 4413 at aw of 0.88 [57], P. acidilactici SP979 at aw of 0.90 [58], and with the combined use of 10 strains of L. plantarum at aw of 0.94 [35].

In terms of sensory evaluation, the use of autochthonous probiotic strains as starter cultures preserved or enhanced the sensory characteristics. For instance, Arief et al. [54] indicated that lamb sausage fermented with L. plantarum IIA-2C12 received higher score for aroma, color, and texture than the sausage elaborated without a starter culture. In a posterior study, the same group indicated similar acceptance of color, aroma, and texture among control (without) and two beef sausages inoculated with probiotics (L. plantarum IIA-2C12 and L. acidophilus IIA-2B4) [55]. Another relevant outcome 
indicated by this experiment was the influence of probiotic starter culture on the volatile compounds of the final product. According to the authors, the main influence was observed in the composition of volatile fraction, which suggested the influence in the metabolic process that generated the volatile compounds. For instance, the generation of acetic acid was enhanced in sausages elaborated with probiotics in comparison to control while an opposite effect was reported for ethyl alcohol.

In a study with the probiotic strain L. plantarum L125 in the production of pork sausage, a significant increase in the scores of redness, raw odor, and acidic taste during processing and storage in comparison to sausage produced without a starter culture was found [56]. The other sensory attributes (odor; taste; appearance; texture; paleness and oily appearance; smoking odor; acidic, aftertaste, juicy, salty, sweet, and spicy taste) were not affected by the probiotic starter culture. A similar outcome was reported for the use of P. acidilactici SP979 in Spanish salchichón where only the color was affected by the probiotic culture and no significant effect was reported for other attributes (flavor, taste, texture, odor, and acceptability) [58].

In addition to the effect in technological properties, the autochthonous probiotic starter cultures can also influence the cholesterol and biogenic amine content, as indicated by Kantachote et al. [60]. According to the authors, the mixed starter culture of P. pentosaceus HN8 and L. namurensis NH2 caused a reduction in seven biogenic amines (cadaverine, histamine, $\beta$-phenylethylamine, putrescine, spermidine, spermine, and tyramine) and also reduced the total cholesterol content in comparison to control and commercially produced Nham (a traditional Thai fermented pork sausage). A related experiment with P. acidilactici SP979 in the production of Spanish salchichón indicated no significant effect in the accumulation of biogenic amines after the ripening period [58]. In the context of food processing, autochthonous probiotic strains can be applied in the production of fermented meat products. Many advantages can be cited: fast and persistent colonization during and after processing, inhibition of competitive microorganisms (especially pathogenic bacteria in both in vitro tests and meat product), and preservation or enhancement of sensory properties.

\section{Conclusions}

The autochthonous microorganisms found in meat products have great potential to be applied as probiotic starter cultures. Consequently, meat products produced with starter cultures can be improved beyond their current use for a functional food market (especially for thermally treated meat products with thermotolerant strains) that has been growing in the last years. LAB plays an important role in this specific category of starter culture for the meat industry because of their probiotic potential (resistance to digestion, colonization of small intestine and safety aspects) and satisfactory characteristic from a meat processing point of view (fast colonization of meat mass, development of characteristic sensory attributes, as well as viability during storage).

Author Contributions: Conceptualization, P.E.S.M. and J.M.L.; writing—original draft preparation, P.E.S.M., M.P. and R.D.; writing-review and editing, W.Z., L.X., E.M.F. and J.M.L. All authors have read and agreed to the published version of the manuscript.

Funding: This research received no external funding.

Acknowledgments: Thanks to GAIN (Axencia Galega de Innovación) for supporting this study (grant number IN607A2019/01). Paulo E. S. Munekata acknowledges postdoctoral fellowship support from the Ministry of Economy and Competitiveness (MINECO, Spain) “Juan de la Cierva" program (FJCI-2016-29486). Jose M. Lorenzo is member of the HealthyMeat network, funded by CYTED (ref. 119RT0568).

Conflicts of Interest: The authors declare no conflict of interest.

\section{References}

1. Ojha, K.S.; Kerry, J.P.; Duffy, G.; Beresford, T.; Tiwari, B.K. Technological advances for enhancing quality and safety of fermented meat products. Trends Food Sci. Technol. 2015, 44, 105-116. [CrossRef]

2. Leroy, F.; Geyzen, A.; Janssens, M.; De Vuyst, L.; Scholliers, P. Meat fermentation at the crossroads of innovation and tradition: A historical outlook. Trends Food Sci. Technol. 2013, 31, 130-137. [CrossRef] 
3. Anal, A.K. Quality ingredients and safety concerns for traditional fermented foods and beverages from Asia: A review. Fermentation 2019, 5, 8. [CrossRef]

4. Talon, R.; Leroy, S.; Lebert, I. Microbial ecosystems of traditional fermented meat products: The importance of indigenous starters. Meat Sci. 2007, 77, 55-62. [CrossRef] [PubMed]

5. Shan, L.C.; Henchion, M.; De Brún, A.; Murrin, C.; Wall, P.G.; Monahan, F.J. Factors that predict consumer acceptance of enriched processed meats. Meat Sci. 2017, 133, 185-193. [CrossRef]

6. Leroy, F.; Scholliers, P.; Amilien, V. Elements of innovation and tradition in meat fermentation: Conflicts and synergies. Int. J. Food Microbiol. 2015, 212, 2-8. [CrossRef]

7. Granato, D.; Barba, F.J.; Kovačević, B.D.; Lorenzo, J.M.; Cruz, A.G.; Putnik, P. Functional foods: Product development, technological trends, efficacy testing, and safety. Annu. Rev. Food Sci. Technol. 2020, 11, 93-118. [CrossRef]

8. Khajavi, M.Z.; Abhari, K.; Barzegar, F.; Hosseini, H. Functional meat products: The new consumer's demand. Curr. Nutr. Food Sci. 2020, 16, 260-267. [CrossRef]

9. Bis-Souza, C.V.; Barba, F.J.; Lorenzo, J.M.; Penna, A.L.B.; Barretto, A.C.S. New strategies for the development of innovative fermented meat products: A review regarding the incorporation of probiotics and dietary fibers. Food Rev. Int. 2019, 35, 467-484. [CrossRef]

10. Syngai, G.G.; Gopi, R.; Bharali, R.; Dey, S.; Lakshmanan, G.M.A.; Ahmed, G. Probiotics-The versatile functional food ingredients. J. Food Sci. Technol. 2016, 53, 921-933. [CrossRef]

11. FAO/WHO. Guidelines for the Evaluation of Probiotics in Food; FAO/WHO: London, ON, Canada, 2002.

12. Bis-Souza, C.V.; Pateiro, M.; Domínguez, R.; Penna, A.L.B.; Lorenzo, J.M.; Barretto, A.C.D.S. Impact of fructooligosaccharides and probiotic strains on the quality parameters of low-fat Spanish Salchichón. Meat Sci. 2020, 159, 107936. [CrossRef] [PubMed]

13. Bis-Souza, C.V.; Pateiro, M.; Domínguez, R.; Lorenzo, J.M.; Penna, A.L.B.; Barretto, A.C.D.S. Volatile profile of fermented sausages with commercial probiotic strains and fructooligosaccharides. J. Food Sci. Technol. 2019, 56, 5465-5473. [CrossRef] [PubMed]

14. Kumar, P.; Chatli, M.K.; Verma, A.K.; Mehta, N.; Malav, O.P.; Kumar, D.; Sharma, N. Quality, functionality, and shelf life of fermented meat and meat products: A review. Crit. Rev. Food Sci. Nutr. 2017, 57, 2844-2856. [CrossRef] [PubMed]

15. Food and Drug Administration Microorganisms \& Microbial-Derived Ingredients Used in Food (Partial List). Available online: https:/www.fda.gov/food/generally-recognized-safe-gras/microorganisms-microbialderived-ingredients-used-food-partial-list (accessed on 5 June 2020).

16. Lorenzo, J.M.; Munekata, P.E.S.; Domínguez, R. Role of autochthonous starter cultures in the reduction of biogenic amines in traditional meat products. Curr. Opin. Food Sci. 2017, 14, 61-65. [CrossRef]

17. Chen, C.-L.; Liou, J.-M.; Lu, T.-M.; Lin, Y.-H.; Wang, C.-K.; Pan, T.-M. Effects of Vigiis 101-LAB on a healthy population's gut microflora, peristalsis, immunity, and anti-oxidative capacity: A randomized, double-blind, placebo-controlled clinical study. Heliyon 2020, 6, e04979. [CrossRef]

18. Mafi, A.; Namazi, G.; Soleimani, A.; Bahmani, F.; Aghadavod, E.; Asemi, Z. Metabolic and genetic response to probiotics supplementation in patients with diabetic nephropathy: A randomized, double-blind, placebo-controlled trial. Food Funct. 2018, 9, 4763-4770. [CrossRef]

19. Bjarnason, I.; Sission, G.; Hayee, B.H. A randomised, double-blind, placebo-controlled trial of a multi-strain probiotic in patients with asymptomatic ulcerative colitis and Crohn's disease. Inflammopharmacology 2019, 27, 465-473. [CrossRef]

20. Laranjo, M.; Elias, M.; Fraqueza, M.J. The use of starter cultures in traditional meat products. J. Food Qual. 2017, 2017, 1-18. [CrossRef]

21. Cruxen, C.E.D.S.; Funck, G.D.; Haubert, L.; Dannenberg, G.D.S.; Marques, J.D.L.; Chaves, F.C.; da Silva, W.P.; Fiorentini, Â.M. Selection of native bacterial starter culture in the production of fermented meat sausages: Application potential, safety aspects, and emerging technologies. Food Res. Int. 2019, 122, 371-382. [CrossRef]

22. Oelschlaeger, T.A. Mechanisms of probiotic actions-A review. Int. J. Med. Microbiol. 2010, 300, 57-62. [CrossRef]

23. Shokryazdan, P.; Jahromi, M.F.; Liang, J.B.; Ho, Y.W. Probiotics: From isolation to application. J. Am. Coll. Nutr. 2017, 36, 666-676. [CrossRef] [PubMed]

24. Yadav, R.; Shukla, P. An overview of advanced technologies for selection of probiotics and their expediency: A review. Crit. Rev. Food Sci. Nutr. 2017, 57, 3233-3242. [CrossRef] [PubMed] 
25. Pereira, G.V.D.M.; Neto, D.P.D.C.; Junqueira, A.C.D.O.; Karp, S.G.; Letti, L.A.J.; Júnior, A.I.M.; Soccol, C.R. A Review of selection criteria for starter culture development in the food fermentation industry. Food Rev. Int. 2020, 36, 135-167. [CrossRef]

26. Federici, S.; Ciarrocchi, F.; Campana, R.; Ciandrini, E.; Blasi, G.; Baffone, W. Identification and functional traits of lactic acid bacteria isolated from Ciauscolo salami produced in Central Italy. Meat Sci. 2014, 98, 575-584. [CrossRef]

27. Han, Q.; Kong, B.; Chen, Q.; Sun, F.; Zhang, H. In vitro comparison of probiotic properties of lactic acid bacteria isolated from Harbin dry sausages and selected probiotics. J. Funct. Foods 2017, 32, 391-400. [CrossRef]

28. Wang, J.; Wang, J.; Yang, K.; Liu, M.; Zhang, J.; Wei, X.; Fan, M. Screening for potential probiotic from spontaneously fermented non-dairy foods based on in vitro probiotic and safety properties. Ann. Microbiol. 2018, 68, 803-813. [CrossRef]

29. Barbosa, J.; Borges, S.; Teixeira, P. Selection of potential probiotic Enterococcus faecium isolated from Portuguese fermented food. Int. J. Food Microbiol. 2014, 191, 144-148. [CrossRef]

30. Moreno, I.; Marasca, E.T.G.; De Sá, P.B.Z.R.; Moitinho, D.S.J.; Marquezini, M.G.; Alves, M.R.C.; Bromberg, R. Evaluation of probiotic potential of bacteriocinogenic lactic acid bacteria strains isolated from meat products. Probiotics Antimicrob. Proteins 2018, 10, 762-774. [CrossRef]

31. Petrović, T.D.Ž.; Ilić, P.D.; Grujović, M.Z.; Mladenović, K.G.; Kocić-Tanackov, S.D.; Čomić, L.R. Assessment of safety aspect and probiotic potential of autochthonous Enterococcus faecium strains isolated from spontaneous fermented sausage. Biotechnol. Lett. 2020, 42, 1513-1525. [CrossRef]

32. Vieira, K.C.D.O.; Ferreira, C.D.S.; Bueno, E.B.T.; de Moraes, Y.A.; Toledo, A.C.C.G.; Nakagaki, W.R.; Pereira, V.C.; Winkelstroter, L.K. Development and viability of probiotic orange juice supplemented by Pediococcus acidilactici CE51. LWT 2020, 130, 109637. [CrossRef]

33. Borah, D.B.Y.; Gogoi, O.; Adhikari, C.; Kakoti, B.B. Isolation and characterization of the new indigenous Staphylococcus sp. DBOCP06 as a probiotic bacterium from traditionally fermented fish and meat products of Assam state. Egypt. J. Basic Appl. Sci. 2016, 3, 232-240. [CrossRef]

34. Klayraung, S.; Viernstein, H.; Sirithunyalug, J.; Okonogi, S. Probiotic properties of lactobacilli isolated from Thai traditional food. Sci. Pharm. 2008, 76, 485-503. [CrossRef]

35. Dias, F.S.; Duarte, W.F.; Santos, M.R.R.M.; Ramos, E.M.; Schwan, R.F. Screening of Lactobacillus isolated from pork sausages for potential probiotic use and evaluation of the microbiological safety of fermented products. J. Food Prot. 2013, 76, 991-998. [CrossRef] [PubMed]

36. Topçu, K.C.; Kaya, M.; Kaban, G. Probiotic properties of lactic acid bacteria strains isolated from pastırma. LWT 2020, 134, 110216. [CrossRef]

37. Yuksekdag, Z.N.; Aslim, B. Assessment of potential probiotic and starter properties of Pediococcus spp. isolated from Turkish-type fermented sausages (Sucuk). J. Microbiol. Biotechnol. 2010, 20, 161-168. [CrossRef]

38. Zommiti, M.; Cambronel, M.; Maillot, O.; Barreau, M.; Sebei, K.; Feuilloley, M.; Ferchichi, M.; Connil, N. Evaluation of probiotic properties and safety of Enterococcus faecium isolated from artisanal Tunisian meat “Dried Ossban". Front. Microbiol. 2018, 9, 1685. [CrossRef]

39. Klingberg, T.D.; Axelsson, L.; Naterstad, K.; Elsser, D.; Budde, B.B. Identification of potential probiotic starter cultures for Scandinavian-type fermented sausages. Int. J. Food Microbiol. 2005, 105, 419-431. [CrossRef]

40. Landeta, G.; Curiel, J.A.; Carrascosa, A.V.; Muñoz, R.; Rivas, D.L.B. Technological and safety properties of lactic acid bacteria isolated from Spanish dry-cured sausages. Meat Sci. 2013, 95, 272-280. [CrossRef]

41. Babić, I.; Markov, K.; Kovačević, D.; Trontel, A.; Slavica, A.; Dugum, J.; Čvek, D.; Svetec, I.K.; Posavec, S.; Frece, J. Identification and characterization of potential autochthonous starter cultures from a Croatian "brand" product "Slavonski kulen". Meat Sci. 2011, 88, 517-524. [CrossRef]

42. Simonová, M.P.; Strompfová, V.; Marciňáková, M.; Lauková, A.; Vesterlund, S.; Moratalla, M.L.; Bover-Cid, S.; Vidal-Carou, C. Characterization of Staphylococcus xylosus and Staphylococcus carnosus isolated from slovak meat products. Meat Sci. 2006, 73, 559-564. [CrossRef]

43. Ratanaburee, A.; Kantachote, D.; Charernjiratrakul, W.; Sukhoom, A. selection of $\gamma$-aminobutyric acid-producing lactic acid bacteria and their potential as probiotics for use as starter cultures in Thai fermented sausages (Nham). Int. J. Food Sci. Technol. 2013, 48, 1371-1382. [CrossRef] 
44. Hernández-Alcántara, A.M.; Wacher, C.; Llamas, M.G.; López, P.; Pérez-Chabela, M.L. Probiotic properties and stress response of thermotolerant lactic acid bacteria isolated from cooked meat products. LWT 2018, 91, 249-257. [CrossRef]

45. Ruiz-Moyano, S.; Martín, A.; Benito, M.J.; Perez-Nevado, F.; Córdoba, M.D.G. Screening of lactic acid bacteria and bifidobacteria for potential probiotic use in Iberian dry fermented sausages. Meat Sci. 2008, 80, 715-721. [CrossRef] [PubMed]

46. Pennacchia, C.; Ercolini, D.; Blaiotta, G.; Pepe, O.; Mauriello, G.; Villani, F. Selection of Lactobacillus strains from fermented sausages for their potential use as probiotics. Meat Sci. 2004, 67, 309-317. [CrossRef] [PubMed]

47. Abid, Y.; Casillo, A.; Gharsallah, H.; Joulak, I.; Lanzetta, R.; Corsaro, M.M.; Attia, H.; Azabou, S. Production and structural characterization of exopolysaccharides from newly isolated probiotic lactic acid bacteria. Int. J. Biol. Macromol. 2018, 108, 719-728. [CrossRef] [PubMed]

48. Arora, M.; Baldi, A. Selective identification and charcterization of potential probiotic strains: A review on comprehensive polyphasic approach. Appl. Clin. Res. Clin. Trials Regul. Aff. 2017, 4, 60-76. [CrossRef]

49. De Vuyst, L.; Falony, G.; Leroy, F. Probiotics in fermented sausages. Meat Sci. 2008, 80, 75-78. [CrossRef]

50. Työppönen, S.; Petäjä, E.; Mattila-Sandholm, T. Bioprotectives and probiotics for dry sausages. Int. J. Food Microbiol. 2003, 83, 233-244. [CrossRef]

51. Aspri, M.; Papademas, P.; Tsaltas, D. Review on non-dairy probiotics and their use in non-dairy based products. Fermentation 2020, 6, 30. [CrossRef]

52. Min, M.; Bunt, C.R.; Mason, S.L.; Hussain, M.A. Non-dairy probiotic food products: An emerging group of functional foods. Crit. Rev. Food Sci. Nutr. 2019, 59, 2626-2641. [CrossRef]

53. Campaniello, D.; Speranza, B.; Bevilacqua, A.; Altieri, C.; Corbo, M.R.; Sinigaglia, M. Industrial validation of a promising functional strain of Lactobacillus plantarum to improve the quality of Italian sausages. Microorganisms 2020, 8, 116. [CrossRef] [PubMed]

54. Arief, I.I.; Wulandari, Z.; Aditia, E.L.; Baihaqi, M.; Noraimah; Hendrawan. Physicochemical and microbiological properties of fermented lamb sausages using probiotic Lactobacillus plantarum IIA-2C12 as starter culture. Procedia Environ. Sci. 2014, 20, 352-356. [CrossRef]

55. Arief, I.I.; Afiyah, D.N.; Wulandari, Z.; Budiman, C. Physicochemical properties, fatty acid profiles, and sensory characteristics of fermented beef sausage by probiotics Lactobacillus plantarum IIA-2C12 or Lactobacillus acidophilus IIA-2B4. J. Food Sci. 2016, 81, M2761-M2769. [CrossRef] [PubMed]

56. Pavli, F.G.; Argyri, A.A.; Chorianopoulos, N.G.; Nychas, G.J.E.; Tassou, C.C. Effect of Lactobacillus plantarum L125 strain with probiotic potential on physicochemical, microbiological and sensorial characteristics of dry-fermented sausages. Lwt 2020, 118, 108810. [CrossRef]

57. Pragalaki, T.; Bloukas, J.G.; Kotzekidou, P. Inhibition of Listeria monocytogenes and Escherichia coli O157: H7 in liquid broth medium and during processing of fermented sausage using autochthonous starter cultures. Meat Sci. 2013, 95, 458-464. [CrossRef]

58. Ruiz-Moyano, S.; Martín, A.; Benito, M.J.; Hernández, A.; Casquete, R.; Córdoba, D.g.M. Application of Lactobacillus fermentum HL57 and Pediococcus acidilactici SP979 as potential probiotics in the manufacture of traditional Iberian dry-fermented sausages. Food Microbiol. 2011, 28, 839-847. [CrossRef]

59. Mainar, M.S.; Stavropoulou, D.A.; Leroy, F. Exploring the metabolic heterogeneity of coagulase-negative staphylococci to improve the quality and safety of fermented meats: A review. Int. J. Food Microbiol. 2017, 247, 24-37. [CrossRef]

60. Kantachote, D.; Ratanaburee, A.; Sukhoom, A.; Sumpradit, T.; Asavaroungpipop, N. Use of $\gamma$-aminobutyric acid producing lactic acid bacteria as starters to reduce biogenic amines and cholesterol in Thai fermented pork sausage (Nham) and their distribution during fermentation. LWT 2016, 70, 171-177. [CrossRef]

61. Amit, S.K.; Uddin, M.M.; Rahman, R.; Islam, S.M.R.; Khan, M.S. A review on mechanisms and commercial aspects of food preservation and processing. Agric. Food Secur. 2017, 6, 1-22. [CrossRef]

Publisher's Note: MDPI stays neutral with regard to jurisdictional claims in published maps and institutional affiliations. 